\title{
Gastrointestinal involvement in juvenile systemic sclerosis: development of recommendations for screening and investigation
}

\author{
Clare Pain ${ }^{1}$, Tamas Constantin², Eilleen Baildem ${ }^{1}$, Christian Beyer ${ }^{3}$, Henning Lenhartz ${ }^{4}$, Michael Blackley ${ }^{5}$, \\ Dana Nemcova ${ }^{6}$, Clarissa Pilkington ${ }^{7}$, Ivan Foeldvari ${ }^{8^{*}}$, PRES Scleroderma Working Group \\ From 21st European Pediatric Rheumatology (PReS) Congress \\ Belgrade, Serbia. 17-21 September 2014
}

\section{Introduction}

There are currently no agreed recommendations on how to investigate children for gastrointestinal (GI) involvement in Juvenile Systemic Sclerosis (JSSc). The aim of screening is to detect disease early to facilitate early aggressive therapy and improve outcomes. GI involvement at diagnosis incurs a worse outcome [1]. Most deaths occur early in the disease course $[1,2]$.

\section{Objectives}

To develop recommendations for investigation of GI involvement in JSSc, based on paediatric evidence and where this was lacking, consensus expert agreement.

\section{Methods}

Members of the PRES Scleroderma Working Group were invited to participate; additionally a paediatric gastroenterologist was invited. A nominal group technique was used. $75 \%$ consensus was defined as agreement.

\section{Results}

Table 1 shows the recommendations for screening for GI involvement at baseline and at defined time points from diagnosis. Other recommendations agreed by the group which are relevant at any stage in the disease course are as follows:

\section{Conclusion}

JSSc has a significant mortality particularly early on in the disease course. The objective of an aggressive screening program is to identify GI involvement at a stage which may be amenable to treatment. The recommendations developed by this group aim to standardise care and improve outcomes in this rare disease.

Table 1

\begin{tabular}{|c|c|c|}
\hline \multirow[t]{4}{*}{ Gastrointestinal } & \multicolumn{2}{|l|}{ Baseline } \\
\hline & \multicolumn{2}{|c|}{$\begin{array}{l}\text { All patients should have a barium swallow to assess for dysmotility or stricture and } 24 \text { hour pH monitoring for GORD anc } \\
\text { progress to upper Gl endoscopy if any abnormality detected }\end{array}$} \\
\hline & \multicolumn{2}{|l|}{ Follow-up } \\
\hline & Every 3 years or sooner if worsening lung involvement and/or worsening Gl symptoms & $\begin{array}{l}\text { Upper Gl endoscopy } \\
\text { Barium swallow } \\
24 \text { hours pH monitoring }\end{array}$ \\
\hline
\end{tabular}

*screening guidelines are based on asymptomatic patients. However, children may need more frequent monitoring depending on clinical status and abnormalities detected on previous investigation.

${ }^{8}$ Pediatric Rheumatology, Hamburg, Germany

Full list of author information is available at the end of the article 


\section{Disclosure of interest}

None declared.

\section{Abbreviations}

BP: blood pressure; ECG: electrocardiogram; ECHO: echocardiogram; MRI: magnetic resonance imaging; HRCT: high resolution computerised tomography; PFT: DLCO pulmonary function tests with diffusion capacity of lung for carbon monoxide; 6MWT: 6 minute walk test; NT BNP: N-terminal pro-brain natriuretic peptide; GORD: gastro-oesophageal reflux disease.

\section{Authors' details}

'Pediatric Rheumatology, Liverpool, UK. ${ }^{2}$ Pediatric Rheumatology, Budapest, Hungary. ${ }^{3}$ Pediatric Cardiology, Hamburg, Germany. ${ }^{4}$ Pediatric

Gastroenterology, Hamburg, Germany. ${ }^{5}$ Pediatric Rheumatology, Indiana,

USA. ${ }^{6}$ Pediatric Rheumatology, Prague, Czech Republic. ${ }^{7}$ Pediatric

Rheumatology, London, UK. ${ }^{8}$ Pediatric Rheumatology, Hamburg, Germany.

Published: 17 September 2014

doi:10.1186/1546-0096-12-S1-P52

Cite this article as: Pain et al:: Gastrointestinal involvement in juvenile systemic sclerosis: development of recommendations for screening and investigation. Pediatric Rheumatology 2014 12(Suppl 1):P52.

\section{Submit your next manuscript to BioMed Central} and take full advantage of:

- Convenient online submission

- Thorough peer review

- No space constraints or color figure charges

- Immediate publication on acceptance

- Inclusion in PubMed, CAS, Scopus and Google Scholar

- Research which is freely available for redistribution

Submit your manuscript at www.biomedcentral.com/submit
Ciomed Central 